\title{
AN INVESTIGATION INTO THE EXTENT TO WHICH THE NATIONAL SENIOR CERTIFICATE EQUIPS UNIVERSITY FINANCE STUDENTS WITH REQUIRED SKILLS
}

\author{
Annelie Oosthuizen* \\ University of Johannesburg \\ annelieo@uj.ac.za \\ Riëtte Eiselen\# \\ University of Johannesburg \\ rjeiselen@uj.ac.za
}

May 2010

\begin{abstract}
Higher education institutions have an obligation to provide graduates with the necessary knowledge and skills to enter the workforce and contribute effectively to the financial and economic development of the country. After 1994, the South African educational system was redesigned. One of the major events in this process was the replacement of the Senior Certificate (NATED 550) by the National Senior Certificate, awarded for the first time in 2008. Questions have been raised as to whether the National Senior Certificate curriculum prepares learners adequately for success in university studies. The purpose of the exploratory research reported on in this article was to investigate the perceptions of students on the skills acquired in the National Senior Certificate, as well as the skills required to succeed in their university studies. The study was conducted amongst the first-year B.Com (Finance) students during the 2009 academic year at a South African higher education institution. The results of the study indicate that these students felt that they lacked some of the critical skills required for academic success at university.
\end{abstract}

\section{Keywords}

Higher Education Institutions; National Senior Certificate; critical skills; academic success; undergraduate students; Financial and Economic Development

\footnotetext{
* Ms Annelie Oosthuizen is an Institutional Researcher in the Division for Institutional Planning and Quality Promotion (DIPQP) at the University of Johannesburg, South Africa.

\# Prof Riëtte Eiselen is an associate professor in the Department of Finance \& Investment Management, Faculty of Economic and Financial Sciences, University of Johannesburg, South Africa.
} 


\section{INTRODUCTION}

Higher education institutions ( $H E l s$ ) have an obligation to provide graduates with the necessary knowledge and skills required for success in the world of work and who can contribute effectively to the financial and economic development of the country. After 1994, the entire educational system in South Africa (SA) was redesigned. One of the major events in this process was the replacement of the Senior Certificate (NATED 550) by the National Senior Certificate (NSC), awarded for the first time in 2008. According to the popular press, this event has resulted in associated "shocks" experienced in SA HEls from 2009 (Mail \& Guardian, 25 June 2009; Cape Times, 7 July 2009).

Not surprisingly, the Grade 12s of 2008 have been described as the 'guinea pigs' or the 'pioneers' of the new education system (Bloch, 2009:2). Questions have been raised as to whether the NSC curriculum adequately prepares learners for success in university studies and whether $\mathrm{HEls}$ can adapt and add value to the 'products' of the NSC (Bitzer, 2009:226).

At the $20^{\text {th }}$ World Economic Forum held in Dar es Salaam in May 2010, Mr Ebrahim Patel, SA Minister of Economic Development, said that it is important to equip learners with skills which are in demand, e.g. finance, business, management and engineering (Die Burger, 6 May 2010). Furthermore, Mr Patel said that if SA's education system does not succeed in equipping learners with the appropriate skills in future, this country's (and this continent's) international competitiveness and unemployment rate will not improve (Die Burger, 6 May 2010).

The purpose of the exploratory research reported on in this article was to investigate the perceptions of first-year students registered for the B.Com (Finance) degree during the 2009 academic year of the skills acquired in the NSC, as well as the skills required to succeed in their university studies. The research was conducted in the Faculty of Economic and Financial Sciences at the University of Johannesburg (UJ). The aim of the study was to determine firstyear, first-time entrant students' perceptions of the extent in which the NSC equipped them to cope with the academic demands of university studies in B.Com (Finance). Those included in the target group all gained university access by means of the NSC. The investigation focused on the respondents' perceptions of the importance of particular skills required for success in their university studies, as well as on the extent to which they had acquired these skills in the NSC.

This research forms part of a larger project undertaken for $\mathrm{PhD}$ degree studies.

\section{LITERATURE REVIEW}

In order to be successful in studying at a university, certain skills are required - skills that should be acquired mainly at secondary school level. In January 2009, most of the first-time university entrants at SA HEls gained access by means of the new NSC, awarded for the first time at the end of 2008. In comparison with the secondary school leavers of previous years, a greater percentage of the Grade $12 \mathrm{~s}$ of 2008 satisfied the admission requirements of SA HEls. Consequently, the first-year student intake of 2009 exceeded the numbers of previous years (UJ Fact Book, 2009). Furthermore, it was noticeable that by the end of the first semester (in June 2009), more first-year students (i.e. first-time entrants) terminated their studies or dropped out of SA HEls than in previous years (Bitzer, 2009:225). These occurrences have led to questions being raised as to whether the NSC curriculum equipped the secondary school learners with the 
necessary skills to achieve academic success at university. Bloch (2009:103) observed that the position of the first-year students has been under scrutiny since the beginning of 2009, in view of claims that the 2008 NSC school-leaving qualification is of a lower standard than the 'previous' matriculation qualification.

One of the most obvious differences between the new NSC and the old NATED 550 (SA's schoolleaving qualification prior to 2008) is the fact that the NSC no longer differentiates between higher grade and standard levels of assessment. Furthermore, the NSC system requires a portfolio, consisting of evidence of continuous assessment in each subject, which carries a $25 \%$ weight in the calculation of the final school-leaving result in each subject (DoE, 2004:14).

The Council for Quality Assurance in General and Further Education and Training (Umalusi) was established in terms of the General and Further Education and Training Quality Assurance Act, 2001 (Act No. 58 of 2001) (DoE, 2004:16). In 2009 Umalusi needed to review its examination systems and published a research report entitled From NATED 550 to the new National Curriculum: Maintaining standards in 2008. The main reason for the Umalusi project was that the first cohort of learners following the new curriculum for the NSC qualification had reached Grade 12 level. The Umalusi research project was specifically designed to provide information on the comparability of the old NATED 550 and the new NSC, and on the comparative difficulty of the examinations associated with each. The idea was that this information would be used to adjudicate the standard of the new NSC exams of 2008, in relation to the standard of the previous Senior Certificate exams.

In addressing the question of whether the NSC curriculum is succeeding in adequately preparing SA learners for university studies, the purpose and outcomes of this curriculum statement should be borne in mind. The Dor (2008:6) defines the NSC qualification as "a planned combination of exit-level learning outcomes and assessment standards, which has a defined purpose and that is intended to provide learners with applied competence and a basis for further learning". Three categories of outcomes are distinguished in the outcomes-based curriculum (Malan, 1997:40), namely:

- Academic outcomes are those outcomes which require learners to demonstrate their ability to think within every discipline, to understand each of the disciplines and to be selfdirected within each discipline.

- Process outcomes relate to skills or abilities, for example learners' ability to work in groups, to be accountable for their work, to make decisions, to solve problems and to communicate.

- Attitude outcomes require that learners should demonstrate a love for learning, concern for others and self-esteem.

All of these outcomes refer to abilities and skills to be acquired by learners. For the purpose of this article, the concept 'skill' refers to "the ability to do something" (Jacobs \& Gawe, 1998:201). A skill is related to a particular context: applying a skill without proper understanding of its context will result in meaningless activities.

In the context of HEls, Mwamwenda's (1995:89) description of cognitive development, which entails "the development of a person's mental capacity to engage in thinking, reasoning, interpretation, understanding, knowledge acquisition, remembering, organising information, analysis and problem-solving", applies.

Bloom (1976:51) stated that various general factors form part of learnt skills that are necessary 
to successfully complete learning tasks. Some of these general factors are: the ability to give attention to a task, study techniques, the ability to use a library and the effective utilisation of time. Under specific factors Bloom (1976:33) indicated the necessity of previously acquired knowledge for the completion of a specific learning task. This he called the 'existing structure of knowledge at the time of learning' (Bloom, 1976:33). Previously acquired concepts, skills, attitudes and appreciations need to be integrated with new learning.

Problem-solving skills, for example, allow students to discover things for themselves and to engage in solving problems (Jacobs \& Gawe, 1998:35, 232): students learn through self-activity, and the development of these skills contributes to the development of a healthy and productive person and allows students to organise, use and derive meaning from the wealth of information at their disposal. Co-operative methods are particularly recommended for problem-solving or when creativity or divergent thinking is called for. Students will firstly develop an elementary set of thinking skills and as they gain confidence in working in groups they may progress to higher, more complex levels of thinking.

Upcraft, Gardner and Associates (1990:76-77) stated that fostering student success and achievement in the first year also requires placing first-year students in courses appropriate to their skills level. When underprepared students are given the tools to succeed in first-year courses, they develop an early pattern of successful academic behaviour. Picklesimer, Hooper and Ginter (1998:272-274) are of the opinion that life skills are necessary to meet the demands placed on young people, thereby implying that increased life skills can be seen as a factor that contributes to career maturity.

Research by Jacobs and Gawe (1998:14-22, 38-45, 72-76) has indicated that the following skills have been associated with successful academic performance at university:

- Decision-making skills: The process of making choices, which is known as 'valuing', compels students to think critically about issues. Students have to weigh the advantages and disadvantages before they make a decision (Jacobs \& Gawe, 1998:45, 73). The capacity to reason inevitably leads to an urge to do things one's own way, to question reality, to express one's own point of view and to propose changes - in other words, to apply critical thinking. However, critical thinking skills are sometimes suppressed because some people feel threatened when their actions or powers are questioned.

- Ability to practically implement learning content: Students should be engaged in meaningful learning which needs to be worthwhile to them, useful to their own lives and of lasting value. Rote memorisation contrasts sharply with meaningful learning. In the participative approach the practice of rote memorisation is strongly discouraged (Jacobs \& Gawe, 1998:76). A main concern of participative educators is the tendency of students to cram vast amounts of useless information into their minds, pretending that they understand the material, only to forget it again shortly after the examination.

- Critical thinking skills: Jacobs and Gawe (1998:72) define critical thinking as a general term which includes "reasoning (to reach conclusions through connected thought), independent thinking (the ability to have an opinion which does not depend on another person's opinion) and creative thinking (thought which is inventive and imaginative)". Critical thinking promotes the ability of students to think for themselves, to use their imagination and to be assertive. Through critical thinking students learn to participate fully in life and not to stand on the sideline while others tell them what to think and do. Unless educators promote critical thinking, they may be guilty of what Paulo Freire (1995:188) has called the banking 
system of education. The danger of a banking type of education is that educators deposit and transfer knowledge into the empty minds of their students. If knowledge is treated like an object - a commodity that can be exchanged - instead of something which people create, students are not given the opportunity to think for themselves or to discover things for themselves.

- The ability to reflect on a variety of strategies to learn more effectively: Jacobs and Gawe (1998:14) described learning as small-scale research. They argue that successful learning is possible only if students search for, and discover, the knowledge that makes them operate confidently in their life-world.

- Self-confidence and positive self-concept: Students are empowered by a positive selfconcept. According to Jacobs and Gawe (1998:18, 22), a student with a positive selfconcept understands his/her own potential, strengths and weaknesses. Furthermore, students with self-confidence and a positive self-concept learn to accept themselves and strive to become the best they can be given their natural endowments.

- Responsible citizenship: Another major task of education is to develop responsible citizens. Responsibility goes hand in hand with discipline. Discipline leads students towards selfcontrol and personal accountability. Students who assume full responsibility for their learning accept that they will perform well only if they apply themselves diligently to their work (Jacobs \& Gawe, 1998:38).

Various other skills, depending on the study field, have also been shown to be associated with academic performance. Economic reasoning ability and the ability to interpret financial information are viewed as critical skills in finance-related study fields (which is the focus of this study). Swart (1994:2) defines financial literacy as "the ability to read information with a financial bearing, to analyse, to evaluate, to identify (and sometimes quantify) those factors that may influence a person's financial situation and future in a positive or negative way". Numerical, reading and comprehension skills are among the factors that contribute to success in B.Com studies, as indicated by Du Plessis, Müller and Prinsloo (2005:685).

In the following paragraphs the research design, methodology and findings will be described.

\section{RESEARCH DESIGN AND METHODOLOGY}

In this study a mixed-methods design (Saunders, Lewis \& Thornhill, 2007:602) was used, namely qualitative focus group discussions together with a quantitative survey of the students in the target population. An advantage of using mixed methods is that it enables triangulation to take place, namely the use of various data collection techniques within one study in order to verify the validity of the results obtained (Henning, Van Rensburg \& Smit, 2004:103). For example, qualitative data collected using semi-structured group interviews may be a valuable way of triangulating quantitative data collected by means such as a survey (Saunders et al., 2007:614).

\subsection{Development of research instruments}

A review of literature informed the design of the questionnaire for the survey which was used for the collection of quantitative data. Questions for the purpose of collecting data on the students' perceptions of the skills required for success and skills acquired in the NSC were informed by the purpose of the UJ's B.Com (Finance) qualification. This, as stated in the UJ 
Faculty of Economic and Financial Sciences Yearbook (2009:34), states that "the students should be able to reflect on their financial management, investment management, financial planning and accounting decisions and applications to assess the effect thereof in the holistic context of finance as a practice".

Furthermore, the formulation of the questions was informed by the critical cross-field outcomes of the NSC (Do\&, 2000:10; Malan, 1997:18-19). The assessment of the NSC is based on the SA Qualifications Authority's (SAQA)'s seven critical cross-field outcomes, namely:

- The ability to identify and solve problems with responsible decisions shown to be the result of critical and creative thinking.

- The ability to work effectively with others as a member of a team, group, organisation and community.

- The ability to organise and manage oneself and one's activities responsibly and effectively.

- The ability to collect, analyse, organise and critically evaluate information.

- The ability to communicate effectively, using visual, mathematical and/or language skills in oral and/or written presentation.

- The ability to use science and technology effectively and critically, showing responsibility towards the environment and the health of others.

- The ability to demonstrate an understanding of the world as a set of related systems by recognising that problem-solving contexts do not exist in isolation.

Furthermore, the DoE (2000:18) recommends that all NSC programmes of learning and all teaching and learning practices make students aware of the importance of:

- reflecting on and exploring a variety of strategies to learn more effectively;

- participating as responsible citizens in the life of local, national and global communities;

- being culturally and aesthetically sensitive across a range of social contexts; and

- exploring education and career opportunities, and developing entrepreneurial opportunities.

In the survey questionnaire, closed-ended questions were posed to provide the respondent with a number of alternative answers to choose from. The key questions formulated for application during the focus group discussions were also informed by the literature. In the focus group discussions, open-ended questions were used to facilitate discussion. The questions probed the students' opinions on, inter alia, their first-year university experience and the extent to which the NSC curriculum equipped them with the necessary skills, knowledge and attitudes to succeed in B.Com (Finance) studies.

\subsection{Population and sampling}

The target group for this study was all first-year B.Com (Finance) students, registered for the full-time degree qualification offered at the UJ's Auckland Park Kingsway Campus in the 2009 academic year. Furthermore, only students who registered for university studies for the first time in 2009 and who gained access to UJ based on the NSC, obtained at a SA public or private school in 2008, were included in the target group. After permission was obtained from the Faculty of 
Economic and Financial Sciences, a survey was conducted during scheduled lecture times in the second semester of 2009, that is, after the students already had one semester of university experience. The sampled population thus only comprised students who had progressed to the second semester. The questionnaire was handed out to 310 first-year B.Com (Finance) students, that is, the total population were approached to participate. All of the students participating in the survey were also invited to participate in the subsequent focus group discussions.

\subsection{Research procedures}

The quantitative survey was conducted in July 2009. The purpose of the survey questionnaire was to establish the perceptions of UJ's B.Com (Finance) first-year students regarding the extent to which their school education (i.e. the NSC) prepared or equipped them to deal successfully with the demands of university studies. After completion of the questionnaire, the respondents were requested to indicate whether they were willing to participate in a focus group discussion on this topic and, with their consent, to provide their names and contact details. The respondents were contacted via email and/or telephone and were invited to attend one of four focus group discussions.

The collection of qualitative data was done by means of focus group discussions, that is a "group interview, composed of a small number of participants, facilitated by a moderator (facilitator of focus group interviews), in which the topic is defined clearly and precisely and there is a focus on enabling and recording interactive discussion between participants" (Saunders et al., 2007:598).

Four focus group discussion sessions, of 60 to 90 minutes each, were conducted in September 2009 and were facilitated by the researcher and supervisor. Based on the survey responses (willingness to participate in the focus group discussions), a random grouping technique was applied according to the individual student's schedule and preference. Students participated in groups of 6 to 8 persons per group. The facilitator ensured that the environment was warm, friendly and relaxed, informed the students of the purpose of the focus group discussions and received the students' written consent that the information they provided could be used for research purposes. The focus group discussions were tape-recorded and transcribed and the participants validated the transcriptions.

\subsection{Ethical aspects}

Permission to conduct the research and to publish the research results was obtained from the Faculty of Economic and Financial Sciences Ethics Committee. Students participated voluntarily in both the survey and the focus group discussions, gave their informed, written consent and were assured, in writing, of their anonymity (in the survey) and the confidentiality of information they had provided. The data obtained was analysed using valid statistical techniques and the research findings are reported in an accurate and scientifically accountable manner.

\section{DISCUSSION OF KEY FINDINGS}

In the quantitative and qualitative analysis, similarities and differences in the students' perceptions of the skills required for success in B.Com (Finance) studies and skills acquired at 
school were identified. These findings confirmed the skills required for university success, as identified in the literature. The analysis of both the quantitative and qualitative data is discussed in more detail in the following paragraphs.

A total of 215 students voluntarily participated in the quantitative phase of the study. The sample constitutes approximately $69.4 \%$ of those in the target population. The survey questionnaire, which was distributed to the students attending class on a pre-arranged date, consisted of four sections: a background section, sections on their academic performances at school and their performance during the first semester at university, as well as a section on their perceptions of skills required for success in their university studies and acquired in the NSC.

The focus of this article is on the section pertaining to skills required and acquired. Respondents were requested to indicate their perceptions regarding each of 35 skills identified from the literature. (This section of the questionnaire is attached in APPENDIX 1.)

Respondents were required to indicate:

- The importance of each of the identified skills for success in their university studies on a four-point scale, namely

\section{Totally unimportant; \\ 2. Unimportant; \\ 3. Important; or \\ 4. Extremely important.}

In other words, they were required to indicate to what extent each skill is required for success in B.Com (Finance).

- The extent to which the NSC prepared them to acquire each particular skill on a four-point scale, namely

1. Poorly;

2. Moderately;

3. Well; or

4. Verywell.

In other words, they were required to indicate the extent to which they acquired the skill during the NSC.

Respondents indicated during the survey that they were willing to join the focus group discussions. A total of 26 students participated in the focus group discussions. The two questions posed to the participants of the focus group discussions were as follows:

- The first question was designed to probe the skills required: "What are the most critical skills that will contribute towards success in B.Com (Finance) studies at university?"

- The second question was designed to probe the skills not yet acquired: "What are the most critical skills that you might have lacked when you started with your first-year university studies?" 


\subsection{Critical skills required for success in B.Com (Finance) studies}

Although a large percentage of respondents did not answer all of the questions in this section of the questionnaire, between $50 \%$ and $75 \%$ of the 215 respondents indicated that each of the skills listed is either important or very important. To identify the skills that are considered to be more important than others, those skills where at least $70 \%$ of the 215 respondents indicated that they were important or very important were identified: These skills are:

- critical thinking skills ( $74 \%$ of the 215 respondents considered it to be important or very important);

- problem-solving skills (73.5\%);

- decision-making skills (73\%);

- analytical thinking skills $(72.6 \%)$;

- $\quad$ self-confidence (71.6\%);

- economic reasoning ability (71.6\%);

- ability to practically implement learning content (70.2\%); and

- organisationalskills (70.2\%).

The quantitative results $(n=215)$ are graphically illustrated in FIGURE 1 (percentages in the graph do not add up to $100 \%$ due to the large percentage of non-responses to questions in this section). Very small percentages of respondents (typically less than 6\%) considered these skills not to be important.

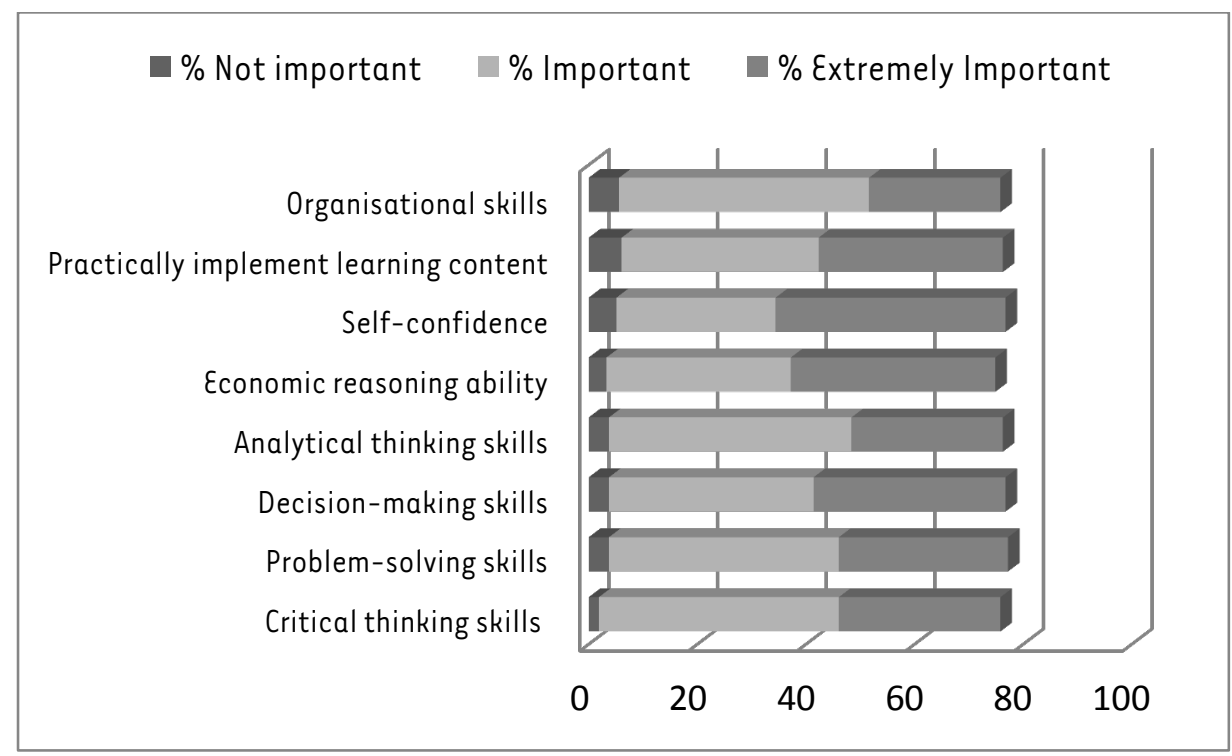

FIGURE 1: $\quad$ Most important skills required for B.Com (Finance) studies

Source: Authors' analysis 
In the qualitative phase of the study the first question also addressed the most critical skills required. The majority of comments relating to this question referred to time management skills (i.e. the ability to be punctual and meet deadlines), which can be considered to be a life skill. The students felt that this is the most critical skill contributing towards success in this programme. The following comments express their concerns, fears, frustrations and sense of inferiority:

- "There are many students who dropped out of varsity due to lack of proper time management and planning."

- "In high school / could study the day before the test or exam. I was always late and end up having to write sick tests. At varsity I cannot only study the night before."

- "Time management helps us to prepare and attend classes on time. It helps us to avoid working under pressure, it goes with proper planning."

- "Do not procrastinate. Some of us think we thrive under pressure but it never works out."

The next most critical skill identified in the focus group discussions also viewed as a life skill, was the ability to work under pressure: Students mentioned that the academic work load at university is much higher, in comparison to what they had to deal with in the NSC. The work pressure associated with this leads to stress, anxiety and, consequently, possibly dropping out of university. Some of the students' comments are as follows:

- "University life is very stressful."

- "Work load is tough, so find people to help you."

Furthermore, it is evident that the use of 'spoon feeding' was a common occurrence among secondary school teachers, and that this has prevented the students from developing their own learning styles. They indicated that they did not know how to study effectively.

The following skill and the comments made in this regard refer to the difficulty in mastering learning content as a result of the teaching methods applied at secondary school level. The ability to practically implement learning content has not been mastered properly, according to the respondents.

- "It is impossible to sleep when you do not understand the chapter and we end up panicking."

- "At school, they spoon-fed us but here (at varsity) we are on our own."

- "The exemplars damaged us. At university the past papers are very different from the actual paper, unlike in high school whereby the exemplar was exactly the same as the exam paper."

- "The NSC Maths Paper l exemplar was very similar to the final paper."

The next most critical skills identified in the focus group discussions are decision-making skills and self-confidence. The comments made by students refer strongly to the life skills required by a first-year student. The 'reality shock' experienced in the transition from school to university varied in relation to their personal experience. It was evident that those students who are used to city life and who are functioning more independently of their families or support systems at home have a greater chance of succeeding at university. Some of the comments made by 
students include:

- "Determination and perseverance is important. Being able to bounce back and pick up the pieces and not losing hope."

- "You need self-motivation! It will be a bumpy road ... push yourself, boost yourself."

- "Most of us come from a protected environment and when we come to varsity, it affects us because of peer pressure, e.g. choosing friends over your books."

In contrast to the findings of the quantitative phase illustrated in FIGURE 1, students participating in the qualitative phase mentioned economic reasoning ability only occasionally, while critical thinking skills, problem-solving skills and analytical thinking skills were not mentioned at all as critical skills required. Furthermore, time management skills were frequently mentioned in the qualitative phase, but were not among the most important skills identified in the quantitative phase.

In order to identify those skills that students considered to be least important, the skills most frequently considered by respondents not to be important for success in B.Com (Finance), in the quantitative study, were identified. These are:

- teamwork ability (21\% of the 215 respondents considered it to be unimportant);

- ability to find relevant information in the library (16.3\%);

- leadership skills (14.4\%);

- creative thinking skills (13\%);

- ability to participate as a responsible citizen in the local community (11.6\%); and

- the ability to be culturally sensitive across the range of social context (10.2\%).

These results should be viewed within the context of this study: the students included in the study have only been exposed to the first semester of study in their first year at university and hence skills such as teamwork ability or the finding of information in the library may not yet have been required of them. It is typically during their second and third year of study where these skills will be required.

\subsection{Skills acquired in the NSC}

In terms of the extent to which each of the skills were acquired during the NSC, at least $35 \%$ but at most $51 \%$ of the 215 respondents considered each of the skills to have been acquired either well or very well, while between $12 \%$ and $32 \%$ of the 215 respondents considered each of the skills to have been acquired either poorly or only to a moderate extent. As was the case for skills required, large percentages of respondents did not answer all of the questions in this section of the questionnaire.

Turning now to those skills that were most frequently considered to have been acquired, the skills indicated by at least $50 \%$ of the 215 respondents to have been acquired either well or very well during the NSC were identified. These skills are:

- the ability to complete projects ( $51 \%$ of 215 respondents indicated they acquired the skill either well or very well);

- calculation skills (51\%); 
- decision-making skills (50\%); and

- the ability to achieve personal goals (50\%).

The results are illustrated in FIGURE 2 (percentages do not add up to 100\% due to high nonresponse percentages to the various questions in this section). Note that for the purpose of a clearer illustration of the responses, categories 1 and 2, namely poorly and to a moderate extent, have been grouped together.

Ability to achieve personal goals

Decision making skills

Calculation skills

Ability to complete projects

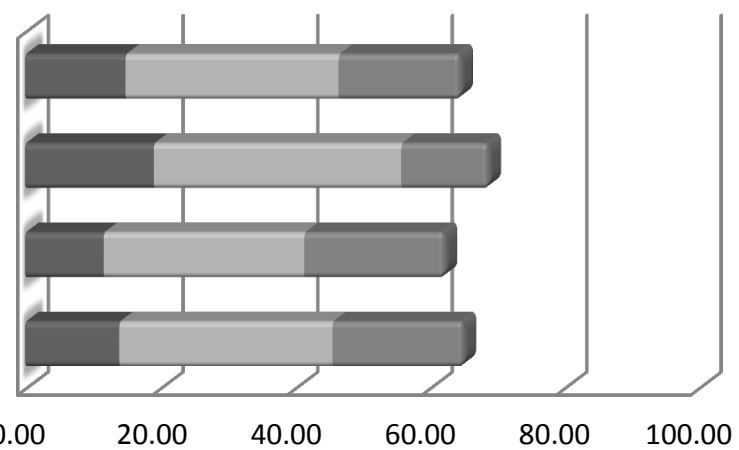

\begin{tabular}{|l|c|c|c|c|}
\cline { 2 - 4 } \multicolumn{1}{c|}{} & $\begin{array}{c}\text { Ability to } \\
\text { complete } \\
\text { projects }\end{array}$ & $\begin{array}{c}\text { Calculation } \\
\text { skills }\end{array}$ & $\begin{array}{c}\text { Decision } \\
\text { making skills }\end{array}$ & $\begin{array}{c}\text { Ability to } \\
\text { achieve } \\
\text { personal goals }\end{array}$ \\
\hline$\square \%$ poor or moderate & 13.95 & 11.63 & 19.07 & 14.88 \\
\hline$\square \%$ Well & 31.63 & 29.77 & 36.74 & 31.63 \\
\hline$\square \%$ Very well & 19.53 & 20.93 & 13.02 & 18.14 \\
\hline
\end{tabular}

\section{FIGURE 2: Most important skills acquired in the NSC}

\section{Source: Authors'analysis}

The skills that were most frequently considered to have been acquired either poorly or to a moderate extent only were also identified. The skills are shown in TABLE 1, together with the percentage of respondents who indicated that they acquired the skill either poorly or to a moderate extent only.

Of interest is the fact that many of the skills identified to be the most important skills for success (FIGURE 1) appear in the table of skills most frequently not acquired (TABLE 1), namely

- critical thinking skills;

- analytical thinking skills;

- economic reasoning ability; and

- the ability to practically implement learning content. 
TABLE 1: Skills most frequently identified as having been acquired poorly or to a moderate extent only, in the NSC

\begin{tabular}{lc}
\hline & $\begin{array}{c}\text { \% of 215 who indicated skills were } \\
\text { acquired poorly or moderately }\end{array}$ \\
\hline Economic reasoning ability & 31.63 \\
Ability to practically implement learning content & 26.05 \\
Ability to find relevant information in the library & 25.12 \\
Creative thinking skills & 24.19 \\
Analytical thinking skills & 23.72 \\
Critical thinking skills & 23.72 \\
Ability to interpret financial information & 23.72 \\
\hline
\end{tabular}

Source: Authors'analysis

This implies that there may be a gap between the extent to which these skills are required for success and the extent to which they were acquired in the NSC.

To further explore the gap between required and acquired skills, the focus was shifted to the students who indicated that they acquired a skill poorly or to a moderate extent only. The number of students who considered the skill to be either important or very important was determined. The skills most frequently considered to be important but not acquired are:

- economic reasoning ability $(30.2 \%$ of the 215 students indicated that this skill was important or very important but was acquired only poorly or to a moderate extent in the NSC);

- ability to practically implement learning content (24.2\%);

- critical thinking skills (23.7\%);

- analytical thinking skills (23.3\%);

- ability to interpret financial information (22.8\%); and

- time management skills (20.5\%).

These results are shown in FIGURE 3.

The response to the second question posed to the respondents during the focus group discussions corresponds with the representation of the results in FIGURE 3 .

In the analysis of the responses by students participating in the focus group discussions, it was evident that the ability to reflect on a variety of strategies to learn more effectively was the skill that the majority of the respondents lacked. Although they were motivated and enthusiastic about their B.Com (Finance) studies, they felt under-equipped to cope with the challenges of learning, mastering and practically implementing the learning content. 


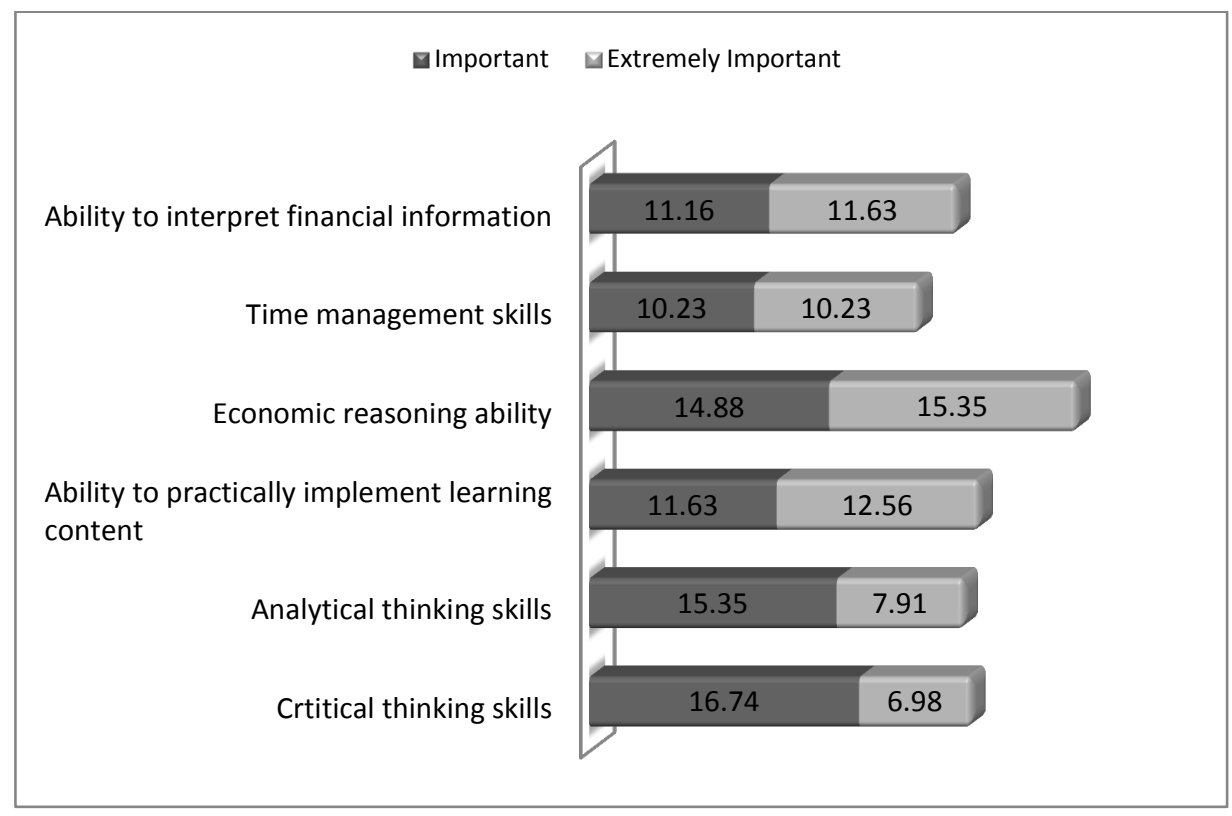

FIGURE 3: Skills not acquired in the NSC, but required in B.Com (Finance) $(n=215)$

Source: Authors'analysis

Some of the comments made are:

- "What works for the next person, doesn't work for you. You need to know your own preference of study methods."

- "Study skills are important because you need to get a different study method and you have to practice."

- "The method to study needs to change. How you studied in high school is different to how you should study in varsity."

Students in the focus group discussions felt that they also lacked analytical thinking skills (ability to analyse and categorise information) and the ability to interpret financial information. Basic computer literacy skills is one of the categories which they seem to have mastered at school, as one of the students commented: "We are the technology generation so computer literacy is not a problem; but to other generations it was a disadvantage."

In summary, the following comments captured the general sentiment of the UJ first-year B.Com (Finance) students of 2009:

- "In high school we could play for the whole year and still pass, varsity is different."

- 'The NSC was too easy. Learners were easily getting A's and B's in high school, it was too simple."

In terms of the skills required but not acquired, there is similarity between the results of the quantitative and qualitative phases. In both phases the ability to practically implement learning content and interpret financial information as well as analytical thinking skills were identified as skills required, but not acquired. The fact that time management skills was identified as the 
most critical skill for success in the qualitative phase is supported by the quantitative phase in the sense that time management skills was one of the skills identified as required, but not acquired. Hence, the results of the quantitative and the qualitative phases of this study supported one another, providing a measure of confirmation of the validity of the results obtained.

\section{DISCUSSION AND SYNTHESIS}

The only academic skill that was identified in both phases as lacking was economic reasoning skills. This does not necessarily imply that these skills were not conveyed to learners in the NSC, but rather that many students taking B.Com (Finance) did not include any of the Economic and Management Sciences subjects, namely Accounting, Business Studies and Economics, in their senior secondary (Further Education and Training) phase subject choices. Indeed, many of the comments made by students in the qualitative focus group discussions related to a lack of proper career advice. This issue should indeed have been addressed in the compulsory subject, Life Orientation, as should time management and organisational skills. However, in practice this subject is viewed (based on the comments made during the qualitative focus group discussions) by most students as a 'joke' and has also been shown to be the easiest subject in the NSC (the highest number of distinctions were achieved in Life Orientation, compared to the results in all of the NSC subjects assessed in November 2008) (Umalusi, 2009:3).

The foresight of the NSC curriculum designers should be commended, especially in view of the fact that the largest percentage of students indicated that the skills that the subject Life Orientation aimed to acquire are perceived to be amongst the most important skills required for academic success at university. Unfortunately, the results of this study have indicated that Life Orientation is not being effectively implemented or taken seriously by the learners.

Furthermore, the results of this study reflect on the implementation of the NSC rather than the content of the curriculum. The Grade 12s of 2008 felt that they were coached and spoon-fed, and the onus rests upon the educators to improve in this regard. Lecturers at SA HEls should take cognisance of these issues in planning their teaching and learning strategies. Tinto (1993:4) states that the key to successful student retention lies with the $\mathrm{HEl}$; it resides in the ability of the lecturers to apply what is known about student retention to the specific situation in which the institution finds itself.

It is of importance to note that the results of this study pertain to the perceptions of students. The perceptions of lecturers on these issues are avenues to be explored in future.

\section{CONCLUSION}

HEls have an obligation to provide graduates with the necessary knowledge and skills to enter the workforce and to contribute effectively to the financial and economic development of the country. The results of this article provide an understanding of the implications and challenges for HEls in SA, resulting from the implementation of the NSC. Questions have been raised and answers have been sought as to whether the NSC curriculum adequately prepares learners for success in university studies; and whether HEls can adapt and add value to the 'products' of the NSC. Mwamwenda (1995:116) states that skills form part of a holistic approach to curriculum construction, that the most common criticism of secondary schools is that they fail to prepare 
young people for the world of work, and that learners fail to develop essential life skills. The students' readiness for higher education can thus be described as a combination of maturity, ability and prior knowledge.

The findings reported in this article are based on both a quantitative and a qualitative enquiry. The results of the study indicate that the students felt that they lacked some of the critical skills required for academic success at university. While it was expected by the researchers that curriculum-related skills would be lacking in first-year students, the results of this study show that those skills contributing to success at university, and lacking in those who enter university for the first time, are life skills rather than academic skills, e.g. time management skills.

Bloch (2009:29) recognises that "change will not happen quickly or overnight". Still, there are many things that can be done immediately that would make a difference. Furthermore, he states that "though there is no quick fix, if we do not start now, with urgency, with unity, we will never achieve anything in the long term either. Without a sense of urgency, our country will surely end in serious trouble, and the loss of our human potential will be unforgiveable" (Bloch, 2009:29).

\section{REFERENCES}

Bitzer, E.M. (2009). Academic and social integration in three first-year groups: A holistic perspective. South African Journal of Higher Education, 23(2), pp. 225-245.

Bloch, G. (2009). The Toxic Mix: What's wrong with South Africa's schools and how to fix it. Cape Town: Tafelberg.

Bloom, B.S. (1976). Human Characteristics and School Learning. New York: McGraw-Hill.

Department of Education. (2008). National Curriculum Statement Grade 10-12. NSTF Workshop. CSIR.

Department of Education. (2000). South African Curriculum for the twenty first century. Report of the review committee on Curriculum 2005. Pretoria.

Department of Education. (2004). National Policy on Assessment and pualifications for Schools in the General Education and Training Band. Pretoria.

Du Plessis, A., Müller, H. \& Prinsloo, P. (2005). Determining the profile of the successful first-year accounting student. South African Journal of Higher Education, 19(4), pp. 684-698.

Freire, P. (1995). Pedagogy of the Oppressed. New York: Penguin Books.

Gower, P. (2009). Dear Minister Nzimande. Mail \& Guardian, 25 June 2009.

Henning, E., Van Rensburg, W. \& Smit, B. (2004). Finding your way in qualitative research. Pretoria: Van Schaik Publishers.

Jacobs, M. \& Gawe, N. (ed.) (1998). Teaching-Learning Dynamics: A participative approach. Johannesburg: Heinemann.

Malan, B. (1997). Excellence through outcomes. Pretoria: Kagiso Publishers.

Mwamwenda, T.S. (1995). Educational Psychology. An African perspective, $2^{\text {nd }}$ edition. Durban: Heinemann.

Picklesimer, B.K., Hooper, D.R. \& Ginter, E.J. (1998). Life-skills, adolescents, and career choices. 
Journal of Mental Health Counselling, 20(3), pp. 272-282.

Saunders, M., Lewis, P. \& Thornhill, A. (2007). Research methods for business students, $4^{\text {th }}$ edition. Essex: Prentice Hall.

Scott, I. (2009). University Challenge. Cape Times. 7 July 2009.

Swart, N.J. (1994). The economic empowerment of employees by means of personal financial planning advice. $6^{\text {th }}$ annual conference of SAIMS. Cape Town. 5-6 September 1994.

Tinto, V. (1993). Rethinking the causes and cures of student attrition, $2^{\text {nd }}$ edition. Chicago: The University of Chicago Press.

Umalusi. (2009). From NATED 550 to the new National Curriculum: maintaining standards in 2008:

Report - Part 1: Overview. Pretoria: Council for Quality Assurance in General and Further Education and Training.

University of Johannesburg. (2009). Fact Book 2009. Section A: Student Enrolments 2009.

Johannesburg.

University of Johannesburg. (2009). Undergraduate and Postgraduate year book of the Faculty of Economic and Financial Sciences. Johannesburg.

Upcraft, M.L., Gardner, J.N. \& Associates. (1990). The Freshman year experience: Helping students to survive and succeed in college. San Francisco: Josey-Bass Publishers.

Vollgraaff, R. (2010). Afrika 'móét vaardighede kry'. Die Burger Sake-nuus. 6 May 2010. 


\section{APPENDIX 1}

\section{SKILLS ACQUIRED IN THE NSC AND ITS RELEVANCE TO UNIVERSITY STUDIES IN B.COM (FINANCE)}

In this section of the questionnaire, your perceptions regarding the skills you require at university and the extent to which the NSC has prepared you for university are explored.

For each of the skills / abilities listed in the table below, please indicate your response in both Column A and B:

- The importance you attach to the skills or attributes in your university studies of B.Com (Finance).

Use the following scale in Column A:

1. Totally Unimportant;

2. Unimportant;

3. Important;

4. Extremely Important

- The extent to which the NSC (NEW secondary school curriculum) prepared you to acquire that skill or attribute. Use the following scale in Column B:

1. Poorly;

2. Moderately;

3. Well;

4. Very Well 


\begin{tabular}{|c|c|c|c|c|c|c|c|c|c|}
\hline \multirow{2}{*}{\multicolumn{2}{|c|}{ Type of Skill / Ability }} & \multicolumn{4}{|c|}{$\begin{array}{l}\text { COLUMNA: } \\
\text { Importance in terms of success } \\
\text { performance in B.Com (Finance) }\end{array}$} & \multicolumn{4}{|c|}{$\begin{array}{c}\text { COLUMN B: } \\
\text { Extent to which NSC prepared } \\
\text { you in acquiring these skills }\end{array}$} \\
\hline & & 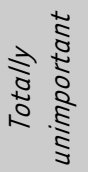 & 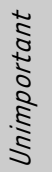 & 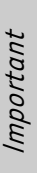 & 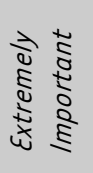 & $\frac{1}{8}$ & $\begin{array}{l}\frac{1}{2} \\
\frac{2}{0} \\
\frac{2}{2} \\
0\end{array}$ & $\stackrel{\bar{a}}{\Xi}$ & $\begin{array}{l}\frac{1}{2} \\
\frac{a}{2}\end{array}$ \\
\hline 1 & Problem solving skills & 1 & 2 & 3 & 4 & 1 & 2 & 3 & 4 \\
\hline 2 & Decision-making skills & 1 & 2 & 3 & 4 & 1 & 2 & 3 & 4 \\
\hline 3 & $\begin{array}{l}\text { Critical thinking skills } \\
\text { (reflective judgement) }\end{array}$ & 1 & 2 & 3 & 4 & 1 & 2 & 3 & 4 \\
\hline 4 & $\begin{array}{l}\text { Analytical thinking skills } \\
\text { (ability to analyse and } \\
\text { categorise information) }\end{array}$ & 1 & 2 & 3 & 4 & 1 & 2 & 3 & 4 \\
\hline 5 & $\begin{array}{l}\text { Creative thinking skills } \\
\text { (generation of new ideas) }\end{array}$ & 1 & 2 & 3 & 4 & 1 & 2 & 3 & 4 \\
\hline 6 & $\begin{array}{l}\text { Ability to practically } \\
\text { implement learning } \\
\text { content }\end{array}$ & 1 & 2 & 3 & 4 & 1 & 2 & 3 & 4 \\
\hline 7 & $\begin{array}{l}\text { Economic reasoning } \\
\text { ability }\end{array}$ & 1 & 2 & 3 & 4 & 1 & 2 & 3 & 4 \\
\hline 8 & Teamwork ability & 1 & 2 & 3 & 4 & 1 & 2 & 3 & 4 \\
\hline 9 & Organisation skills & 1 & 2 & 3 & 4 & 1 & 2 & 3 & 4 \\
\hline 10 & Leadership skills & 1 & 2 & 3 & 4 & 1 & 2 & 3 & 4 \\
\hline 11 & Self-confidence & 1 & 2 & 3 & 4 & 1 & 2 & 3 & 4 \\
\hline 12 & $\begin{array}{l}\text { Ability to complete } \\
\text { projects }\end{array}$ & 1 & 2 & 3 & 4 & 1 & 2 & 3 & 4 \\
\hline 13 & $\begin{array}{l}\text { Ability to achieve } \\
\text { personal goals }\end{array}$ & 1 & 2 & 3 & 4 & 1 & 2 & 3 & 4 \\
\hline 14 & $\begin{array}{l}\text { Ability to prioritise } \\
\text { activities }\end{array}$ & 1 & 2 & 3 & 4 & 1 & 2 & 3 & 4 \\
\hline 15 & $\begin{array}{l}\text { Ability to work } \\
\text { independently }\end{array}$ & 1 & 2 & 3 & 4 & 1 & 2 & 3 & 4 \\
\hline 16 & $\begin{array}{l}\text { Time management skills } \\
\text { (ability to be punctual } \\
\text { and meet deadlines) }\end{array}$ & 1 & 2 & 3 & 4 & 1 & 2 & 3 & 4 \\
\hline 17 & $\begin{array}{l}\text { Ability to work under } \\
\text { pressure }\end{array}$ & 1 & 2 & 3 & 4 & 1 & 2 & 3 & 4 \\
\hline 18 & $\begin{array}{l}\text { Ability to organise } \\
\text { information in a } \\
\text { meaningful way }\end{array}$ & 1 & 2 & 3 & 4 & 1 & 2 & 3 & 4 \\
\hline 19 & $\begin{array}{l}\text { Ability to critically } \\
\text { evaluate information }\end{array}$ & 1 & 2 & 3 & 4 & 1 & 2 & 3 & 4 \\
\hline 20 & Ability to find relevant & 1 & 2 & 3 & 4 & 1 & 2 & 3 & 4 \\
\hline
\end{tabular}




\begin{tabular}{|c|c|c|c|c|c|c|c|c|c|}
\hline & \multirow{2}{*}{ Type of Skill / Ability } & \multicolumn{4}{|c|}{$\begin{array}{l}\text { COLUMN A: } \\
\text { Importance in terms of success } / \\
\text { performance in B.Com (Finance) }\end{array}$} & \multicolumn{4}{|c|}{$\begin{array}{c}\text { COLUMN B: } \\
\text { Extent to which NSC prepared } \\
\text { you in acquiring these skills }\end{array}$} \\
\hline & & 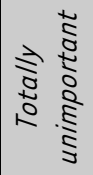 & 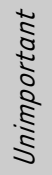 & 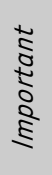 & 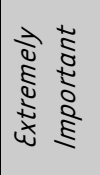 & $\begin{array}{l}\frac{1}{\delta} \\
\vdots \\
0\end{array}$ & $\begin{array}{l}\frac{5}{2} \\
\frac{5}{0} \\
\frac{0}{0} \\
\frac{1}{0}\end{array}$ & $\stackrel{\bar{\omega}}{\Xi}$ & $\frac{\sqrt{0}}{\stackrel{a}{a}}$ \\
\hline & information in the library & & & & & & & & \\
\hline 21 & $\begin{array}{l}\text { Ability to interpret } \\
\text { financial information }\end{array}$ & 1 & 2 & 3 & 4 & 1 & 2 & 3 & 4 \\
\hline 22 & $\begin{array}{l}\text { Mathematical } \\
\text { communication skills e.g. } \\
\text { using graphs and tables }\end{array}$ & 1 & 2 & 3 & 4 & 1 & 2 & 3 & 4 \\
\hline 23 & Calculation skills & 1 & 2 & 3 & 4 & 1 & 2 & 3 & 4 \\
\hline 24 & $\begin{array}{l}\text { Skills to read with } \\
\text { understanding }\end{array}$ & 1 & 2 & 3 & 4 & 1 & 2 & 3 & 4 \\
\hline 25 & Oral communication skills & 1 & 2 & 3 & 4 & 1 & 2 & 3 & 4 \\
\hline 26 & Academic writing skills & 1 & 2 & 3 & 4 & 1 & 2 & 3 & 4 \\
\hline 27 & $\begin{array}{l}\text { Basic computer literacy } \\
\text { skills }\end{array}$ & 1 & 2 & 3 & 4 & 1 & 2 & 3 & 4 \\
\hline 28 & $\begin{array}{l}\text { Ability to understand } \\
\text { global issues and their } \\
\text { impact on the local } \\
\text { community }\end{array}$ & 1 & 2 & 3 & 4 & 1 & 2 & 3 & 4 \\
\hline 29 & $\begin{array}{l}\text { Ability to reflect on a } \\
\text { variety of strategies to } \\
\text { learn more effectively }\end{array}$ & 1 & 2 & 3 & 4 & 1 & 2 & 3 & 4 \\
\hline 30 & $\begin{array}{l}\text { Ability to participate as a } \\
\text { responsible citizen in the } \\
\text { local community }\end{array}$ & 1 & 2 & 3 & 4 & 1 & 2 & 3 & 4 \\
\hline 31 & $\begin{array}{l}\text { Ability to be culturally } \\
\text { sensitive across the range } \\
\text { of social context }\end{array}$ & 1 & 2 & 3 & 4 & 1 & 2 & 3 & 4 \\
\hline 32 & $\begin{array}{l}\text { Adaptability to new } \\
\text { situations }\end{array}$ & 1 & 2 & 3 & 4 & 1 & 2 & 3 & 4 \\
\hline 33 & $\begin{array}{l}\text { Exploring career } \\
\text { opportunities }\end{array}$ & 1 & 2 & 3 & 4 & 1 & 2 & 3 & 4 \\
\hline 34 & $\begin{array}{l}\text { Exploring education } \\
\text { opportunities }\end{array}$ & 1 & 2 & 3 & 4 & 1 & 2 & 3 & 4 \\
\hline 35 & $\begin{array}{l}\text { Developing } \\
\text { entrepreneurial } \\
\text { opportunities }\end{array}$ & 1 & 2 & 3 & 4 & 1 & 2 & 3 & 4 \\
\hline
\end{tabular}

